\title{
The development of a managed aquifer recharge project with recycled water for Chihuahua, Mexico
}

\author{
Adriana Palma Nava ${ }^{1} \cdot$ Fernando J. González Villarreal ${ }^{2} \cdot$ Angélica Mendoza Mata $^{3}$
}

Received: 29 March 2017 / Accepted: 9 February 2018 / Published online: 28 February 2018

(c) The Author(s) 2018. This article is an open access publication

\begin{abstract}
The groundwater supply of the city of Chihuahua, Mexico, is currently unsustainable: demand exceeds replenishment in this area of relatively low precipitation and periodic droughts. The Chihuahua basin hydrologic analysis reflects only two areas of opportunity to increase water supply: water reuse and managed aquifer recharge with treated wastewater. This paper presents the results of project studies carried out by the Institute of Engineering of the UNAM (Universidad Nacional Autónoma de México-National Autonomous University of Mexico) to define the best method for managed aquifer recharge (MAR) with treated wastewater and to identify suitable locations. The work was conducted in accordance with the Mexican guidelines for aquifer recharge with treated wastewater (NOM-014; CONAGUA NOM-014-Requisitos para la recarga artificial de acuíferos con agua residual tratada, 2007) and includes geophysical surveys and unsaturated zone modeling to design a pilot test for intermittent infiltration which will subsequently inform the feasibility and design of a large scale system to recharge $25 \mathrm{Mm}^{3} /$ year.
\end{abstract}

Keywords Aquifer recharge $\cdot$ Groundwater $\cdot$ Modelling $\cdot$ Water quality $\cdot$ Pilot test $\cdot$ Monitoring

\section{Current situation}

The city of Chihuahua is located in northern Mexico at an elevation of $1500 \mathrm{~m}$ above sea level with a population of 930,000 , which is growing at a rate of more than $2 \%$. Mean annual rainfall is $300 \mathrm{~mm}$ which falls mostly in July-September and there is a long dry winter with an average of only $28 \mathrm{~mm}$ falling from December through May. The main source of water supply for the city of Chihuahua currently is groundwater in the "Chihuahua-Sacramento", "TabalaopaAldama" and "Sauz-Encinillas" aquifers. Rural domestic

This article is part of the special issue on Managed Aquifer Recharge.

Adriana Palma Nava

APalmaN@iingen.unam.mx

1 Coordinadora del Grupo de Análisis de Recarga Artificial de Acuíferos de la Red del Agua UNAM, Mexico City, Mexico

2 Coordinador Técnico de la Red del Agua de la Universidad Nacional Autónoma de México (UNAM) e Investigador del Instituto de Ingeniería, UNAM, Mexico City, Mexico

3 Colaboradora del Instituto de Ingeniería, UNAM, Mexico City, Mexico and urban water demands are met through a series of pumping wells that on average extract $118 \mathrm{Mm}^{3}$ annually; surface water supply is insignificant. In addition, $176 \mathrm{Mm}^{3} /$ year of groundwater are extracted for agricultural irrigation purposes.

The estimated urban water consumption of the system is $69 \mathrm{Mm}^{3} /$ year (2000 lps) after an estimated $49 \mathrm{Mm}^{3} /$ year ( $41 \%$ of the total supply) is lost from the urban water system due to leaks. It is estimated that $9 \mathrm{Mm}^{3}$ of the leaked water is lost due to evaporation, $22 \mathrm{Mm}^{3}$ returns to the sewer system and $18 \mathrm{Mm}^{3}$ becomes unintentional recharge to the Chihuahua-Sacramento aquifer (Fig. 1).

Treated wastewater (Fig. 1) amounts to $72 \mathrm{Mm}^{3} /$ year or $2283 \mathrm{l} / \mathrm{s}$. Wastewater is treated at 7 wastewater treatment plants (WWTP): The "South" plant is the one with the highest annual volumes, averaging $54 \mathrm{Mm}^{3}$ (1712 1/s); the "North" WWTP follows with $13 \mathrm{Mm}^{3}$ (412 1/s) and the remaining $5 \mathrm{Mm}^{3}(159 \mathrm{l} / \mathrm{s})$ are treated by five more plants (see Table 1). Wastewater is treated to secondary standard using an activated sludge process to remove settleable solids, and anaerobic digestion of sludge, diffusion of air with fine bubble size with membrane diffusers and anaerobic treatment of primary sludge in two stages. 
Fig. 1 Water balance in the city of Chihuahua $\left(\mathrm{Mm}^{3} /\right.$ year)

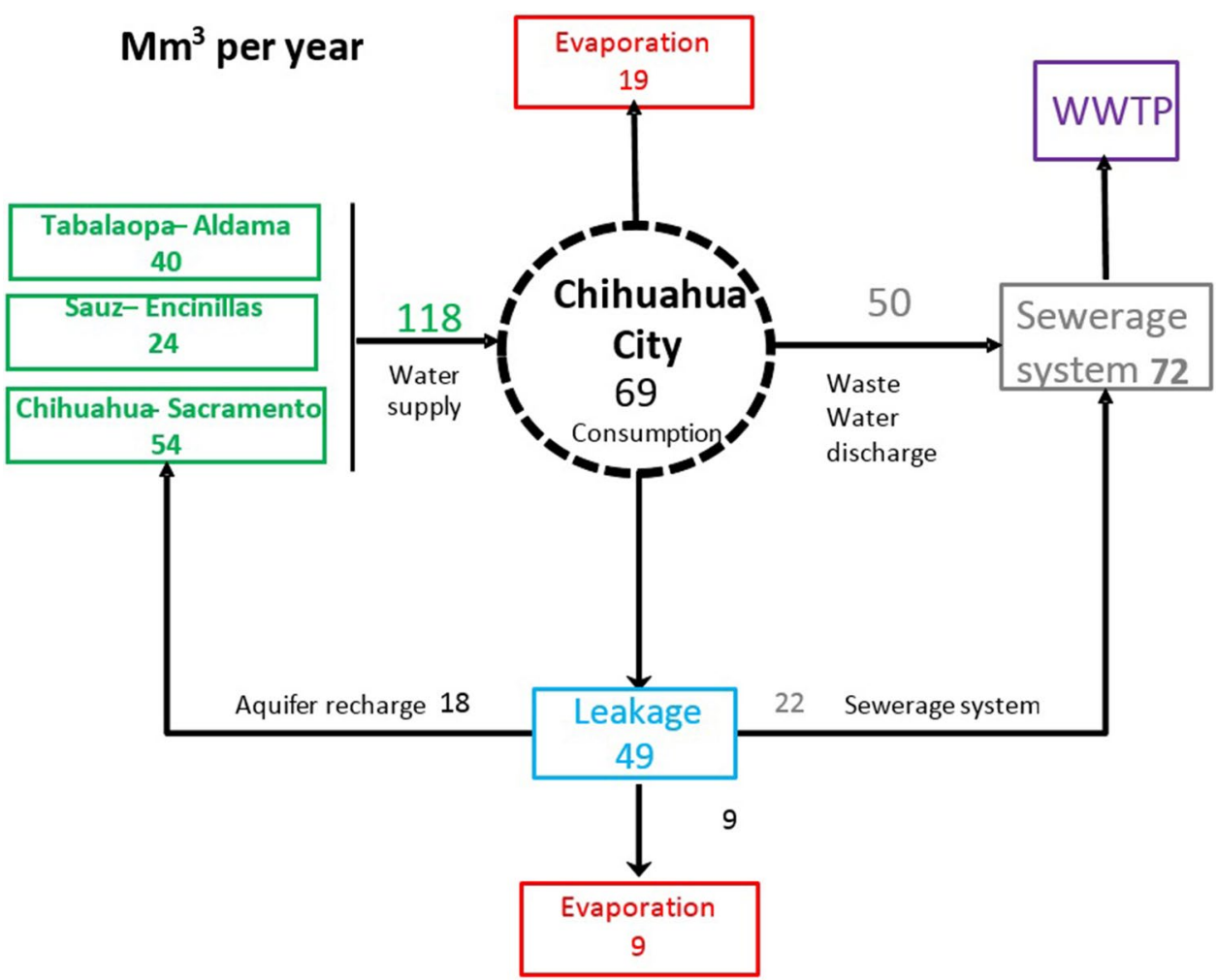

Table 1 Potential availability of water for aquifer recharge

\begin{tabular}{|c|c|c|c|c|}
\hline \multirow{2}{*}{$\begin{array}{l}\text { Waste water } \\
\mathrm{Mm}^{3} / \text { year } \\
72\end{array}$} & \multicolumn{2}{|c|}{$\begin{array}{l}\text { WWTP volume } \\
\mathrm{Mm}^{3} / \text { year }\end{array}$} & \multirow{2}{*}{$\begin{array}{l}\text { Water alloca- } \\
\text { tion } \mathrm{Mm}^{3} / \text { year } \\
7 \text { reuse }\end{array}$} & \multirow{2}{*}{$\begin{array}{l}\text { Water without } \\
\text { allocation } \mathrm{Mm}^{3} / \\
\text { year } \\
6\end{array}$} \\
\hline & North & 13 & & \\
\hline & South & 54 & 35 irrigation & 19 \\
\hline & Others & 5 & - & 5 \\
\hline & & & Potential & 30 \\
\hline
\end{tabular}

$35 \mathrm{Mm}^{3}$ of treated wastewater is currently used for irrigating 3100 ha of open space located mainly along the riverbanks of the Chuvíscar River (an application rate of $1.13 \mathrm{~m} /$ year), and $7 \mathrm{Mm}^{3}$ are used for watering city parks and gardens. Finally, $30 \mathrm{Mm}^{3}$ of treated wastewater remain unallocated for potential future managed aquifer recharge to help supplement city water supply. Actually, this water is discharged to the river.

The Chihuahua basin hydrologic analysis suggests that while water supply leakage is a major issue, and this increases costs of water supply and sewage treatment, it would take a long time to fix and only $9 \mathrm{Mm}^{3} /$ year is really lost from the system if water can be fully recycled (Fig. 1). Of the two non-exclusive areas of opportunity identified to increase water reserves: water reuse and managed aquifer recharge with treated waste water (Dillon et al. 2010), managed aquifer recharge was considered to present improved flexibility for future water supplies. However, there would need to be assurances that this could be done safely, sustainably and economically.

Hence UNAM was asked to assist in evaluating where this could be done and to design a pilot project to demonstrate that this would be safe. The work plan was to follow Mexican standards NOM-014 (CONAGUA 2007) "Requirements for the artificial recharge of aquifers with treated waste water".

Work has advanced through the initial stages of that plan and sites have been identified, one of them has been characterized using geophysics. A pilot plant was designed, unsaturated zone modelling performed to predict its hydraulic and solute transport behavior, and operational approval is awaited for a 6 months intermittent infiltration trial with monitoring to evaluate performance and inform development of a full scale recharge facility.

\section{The NOM-14 procedure for developing MAR projects using treated wastewater}

Mexican standards, called norms, which regulate the development of managed aquifer recharge projects are known as NOM-014 (CONAGUA 2007) "Requirements for the artificial recharge of aquifers with treated waste water". These are part of a wider set of norms that apply to public water supplies and wastewater treatment that are also relevant 
to establishing a MAR project. The requirements outlined in norm NOM-014 determine activities that are necessary to establish a MAR project. These can be summarized as follows:

1. Collating available information and if necessary performing minimal basic studies.

2. Measuring the quality of the treated wastewater.

3. Undertaking a "Pilot" project of recharge in situ.

4. Perform hydrogeochemical analysis.

5. Use of numerical models of flow and transport to predict changes in head and the fate of constituents of recharged water.

6. Meeting the maximum permitted limits of recharge water that CONAGUA allows for parameters that are not regulated by the potable water standards (NOM-127SSA1-1994 1994).

7. Performing any epidemiology studies that CONAGUA may require once the trial results have been reported

8. Respecting minimum distances and residence times between recharge facilities and all production wells.

9. Undertaking of monitoring of hydraulic head, and water quantities and quality during the operation of the project.

\section{Siting of recharge facilities}

To meet the project objectives, several potential managed aquifer recharge locations were studied. Important characteristics making these locations suitable for MAR include their proximity to the recharge water source and availability of land.

The potential locations for managed aquifer recharge projects considered several technical aspects, including local characteristics (Arévalo et al. 2006), economic, social, and legal/administrative considerations, including the ability to adhere to the NOM-014. These represent step one of the NOM-014 process. The process favors infiltration through the unsaturated zone as this provides a further level of treatment, equivalent to slow sand filtration, before water reaches the aquifer. Intermittent infiltration, known as soil-aquifer treatment (SAT) is preferred as a means of assisting with nitrogen removal, and in re-aerating surface soils. It is also helpful from an operating perspective because drying allows desiccation of the biofilm that accumulates on the soil surface during ponding and interrupts the breeding cycle of mosquitos. Hence, the hydraulic conductivity of the unsaturated zone is a consideration for site selection.

The result of these preliminary analyses demonstrated two favorable potential locations for MAR, including the wastewater discharge area of the "North" Waste Water
Treatment Plant (NWWTP) in the river Sacramento, and the area bordering the "South" WWTP (SWWTP), located approximately $1 \mathrm{~km}$ from the Chuvíscar River. Hydrogeological characteristics that make these areas favorable for MAR include that the aquifers are unconfined and dominated by alluvial and fluvial deposits of varied pore-size distribution (high permeability). The water table was also found to be deep. Figure 2 shows the two prospective areas within which treatment facilities could be located.

In accordance with the potential availability of water as presented in Table 1, for the NWWTP, it is proposed to construct water diversions on the river bed to facilitate the infiltration of the $190 \mathrm{l} / \mathrm{s}$ in the first $2 \mathrm{kms}$ of the river. This will increase the natural recharge volume and improve groundwater quality; hence, investigations were performed to characterize the subsurface in this area.

\section{Site characterization}

Studies in this area included surface geophysics using vertical electrical soundings (VES) to estimate the electrical resistivity or conductivity of the underlying lithology, topographic surveys and plotting the bathymetry of Chuvíscar River.

The geophysical studies were conducted using 16 Schlumberger vertical electrical probes (SEVs) each have up to 29 measurements, with a maximum spacing between current electrodes of $1000 \mathrm{~ms}$ and spacing between potential electrodes of $100 \mathrm{~ms}$ (Hernández 2017). For each probe a maximum of 5 splices was done, and at each station an apparent resistivity reading was obtained (in Ohm-m). All probes were acquired with resistivity equipment, induced polarization and natural potential, taking into account the availability of the land to be able to cover as much surface area as possible (Fig. 3).

It should be noted that there is a water well supply located a few meters from the survey. The extraction well has a discharge rate of $55 \mathrm{l} / \mathrm{s}$, and the lithology is reported as a thin layer of silty alluvium at least $4 \mathrm{~ms}$ thick, followed by a sequence with several thick to medium horizons of gravels with variable clay content inter-layered with sand and clay horizons. The well has a depth of $350 \mathrm{~ms}$ and the depth of its initial static water level was greater than $55 \mathrm{~ms}$. A static water level was reported at $100 \mathrm{~ms}$ depth at the time of the vertical electrical surveys.

As a result of the geophysical studies carried out in the SWWTP, it is inferred that the lithology in the first $100 \mathrm{~m}$ of depth is represented mainly by alluvium, composed by layers of gravels and sands that facilitate the infiltration process to the aquifer. Deeper silts and clays are present, but variable 

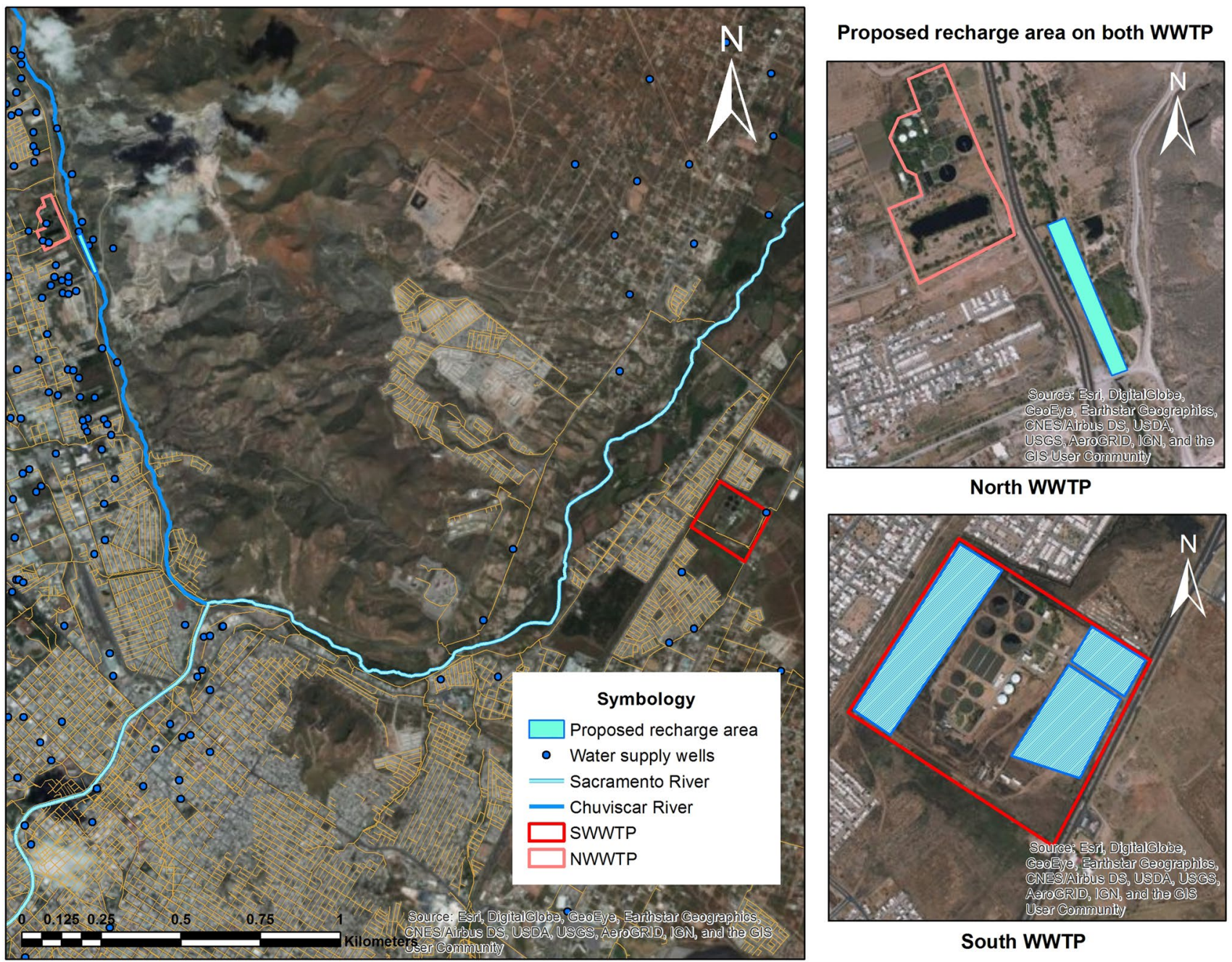

South WWTP

Fig. 2 Waste water treatment plants and proposed recharge area for Chihuahua City

and are not expected to affect the infiltration rates from the pilot recharge basin.

With the data shown in the preceding sections, a conceptual model of the study area beneath the proposed pilot basin was generated. A schematic representation of this is shown in Fig. 4. According to the above, the stratigraphy of the terrain can be divided into five layers. The first two and the fourth layers having characteristics similar to alluvium and gravel, the third layer similar to a sandy medium, and the fifth layer with typical features of silt.

\section{Water quality}

Water quality in the Chihuahua-Sacramento aquifer is reported to be generally good with acceptable values of total dissolved solids and related parameters of the NOM-127SSA1-1994 (1994) for drinking water quality. In relation to the Tabalaopa-Aldama aquifer, the parameters are within the norm, with the exception of one well with high iron content and another well with nitrates in the upper limits which are due to local sources of contamination; pumping has ceased from these wells.

Regarding the water quality of the SWWTP, some of the parameters of the treated effluent monitored are: chemical oxygen demand (COD), biological oxygen demand $\left(\mathrm{BOD}_{5}\right)$, total suspended solids (TSS), sediment solids (SED), fecal coliforms, helminth, grease and oils, methylene blue active substances (SAAM), Kjeldahl total nitrogen (NTK), total nitrogen $\left(\mathrm{N}-\mathrm{NH}_{3}, \mathrm{~N}-\mathrm{NO}_{2}, \mathrm{~N}-\mathrm{NO}_{3}\right), \mathrm{pH}$, temperature, chlorine $\left(\mathrm{CL}_{2}\right)$, and phosphorus $(\mathrm{P})$. Some of the concentrations recorded in December 2012 are shown in Table 2.

Further analyses are currently being performed to determine the relationship between source water quality and NOM-14 standards to determine if further treatment is needed before recharge. Such analyses will also allow comparisons with NOM-27 standards which need to be met at the point of abstraction from the aquifer if the native 


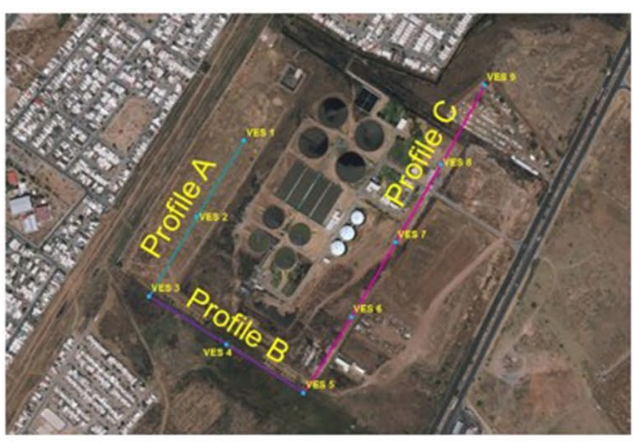

Profiles location
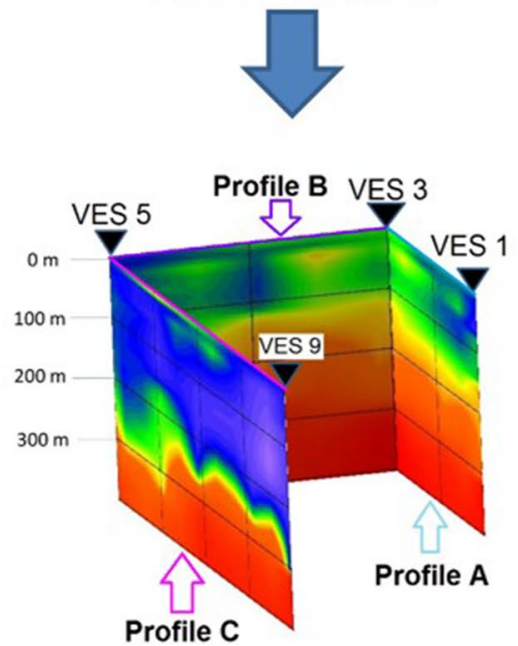

Distribution of Vertical Electric Soundings

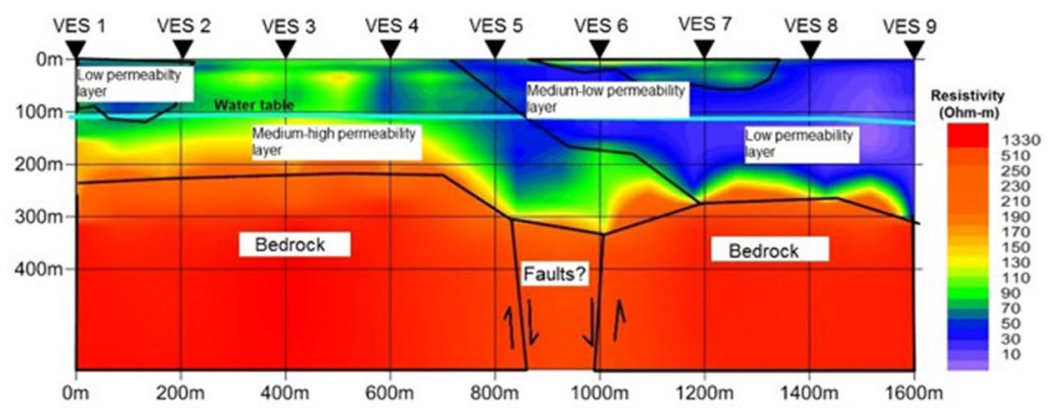

Inverted resistivity from VES data
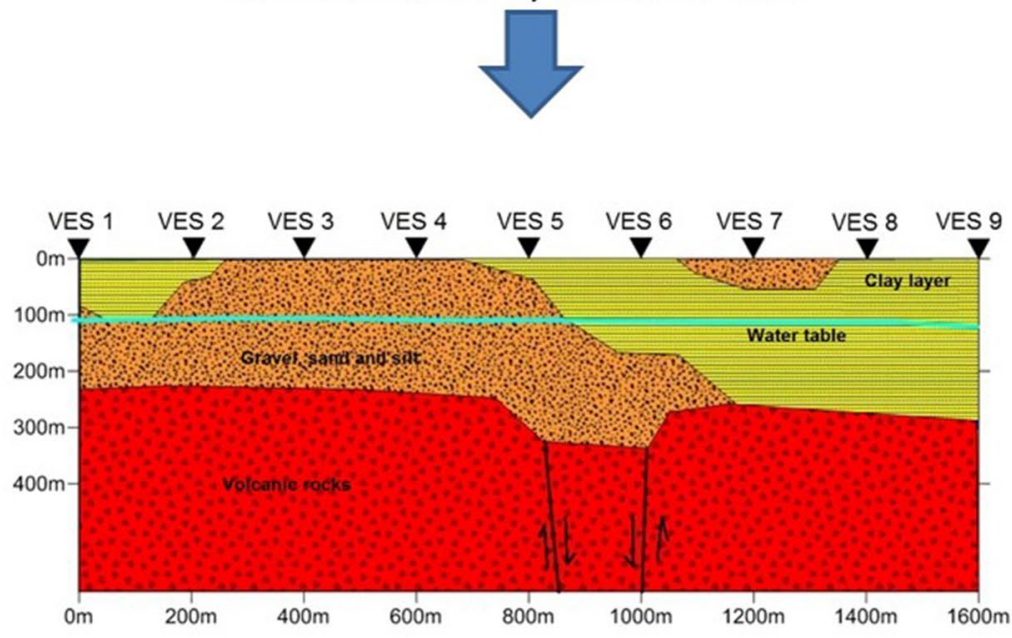

Inferred lithology from VES data

Fig. 3 Localization of the probes and interpretation of the results in the SWWTP

groundwater is used as a drinking water supply. It will also allow comparisons with native groundwater to ensure any existing non-potable uses of groundwater from production wells will not be adversely affected by the MAR operation.

In Table 2 there are too few samples analyzed to date $(0-2)$ to determine the reliability of the analyses and the consistency of the quality of treated wastewater to be used for recharge, which are required to then evaluate whether there is a need for further treatment. Table 2, when updated after more monitoring with more samples and more analyses, is expected to show whether the treated wastewater meets the requirements indicated in NOM-014, regarding the permissible limits of contaminants not regulated by standard $(\mathrm{BOD} \leq 30 \mathrm{mg} / \mathrm{l})$ and $\mathrm{TOC} \leq 16 \mathrm{mg} / \mathrm{l}$, in surface recharge systems. It will also reveal which parameters need to be removed in the vadose zone, and by what proportion to meet groundwater requirements and NOM-127.

Based on the information from the studies and the secondary treatment level of the SWWTP, MAR by means of infiltration lagoons is proposed. The feasibility of this approach will be further evaluated through conducting a pilot project, hydrogeochemical analysis and the development of numerical models. During 6 months of operation of the pilot project, water quality parameters will be monitored, residence time will be evaluated and the amount of water recovered will be recorded, see Fig. 5 (NRMMC, EPHC and NHMRC 2009).

\section{Design of the pilot test}

The aim of the trial with the pilot test is to recharge sufficient water over a period of 6-12 months, so that there will be an observable breakthrough of recharge to the water table with a noticeable piezometric response and water quality response. This will allow a preliminary evaluation of water quality changes during water transport through the unsaturated zone. The design was based on considering the basic parameters of surface soil infiltration rates and hydraulic head. The estimated infiltration rate through the 
Fig. 4 Conceptual geologic model of pilot recharge site
Table 2 Available data on selected water quality parameters for treated effluent, native groundwater and the corresponding standards under the Mexican NOM-014 and NOM-127

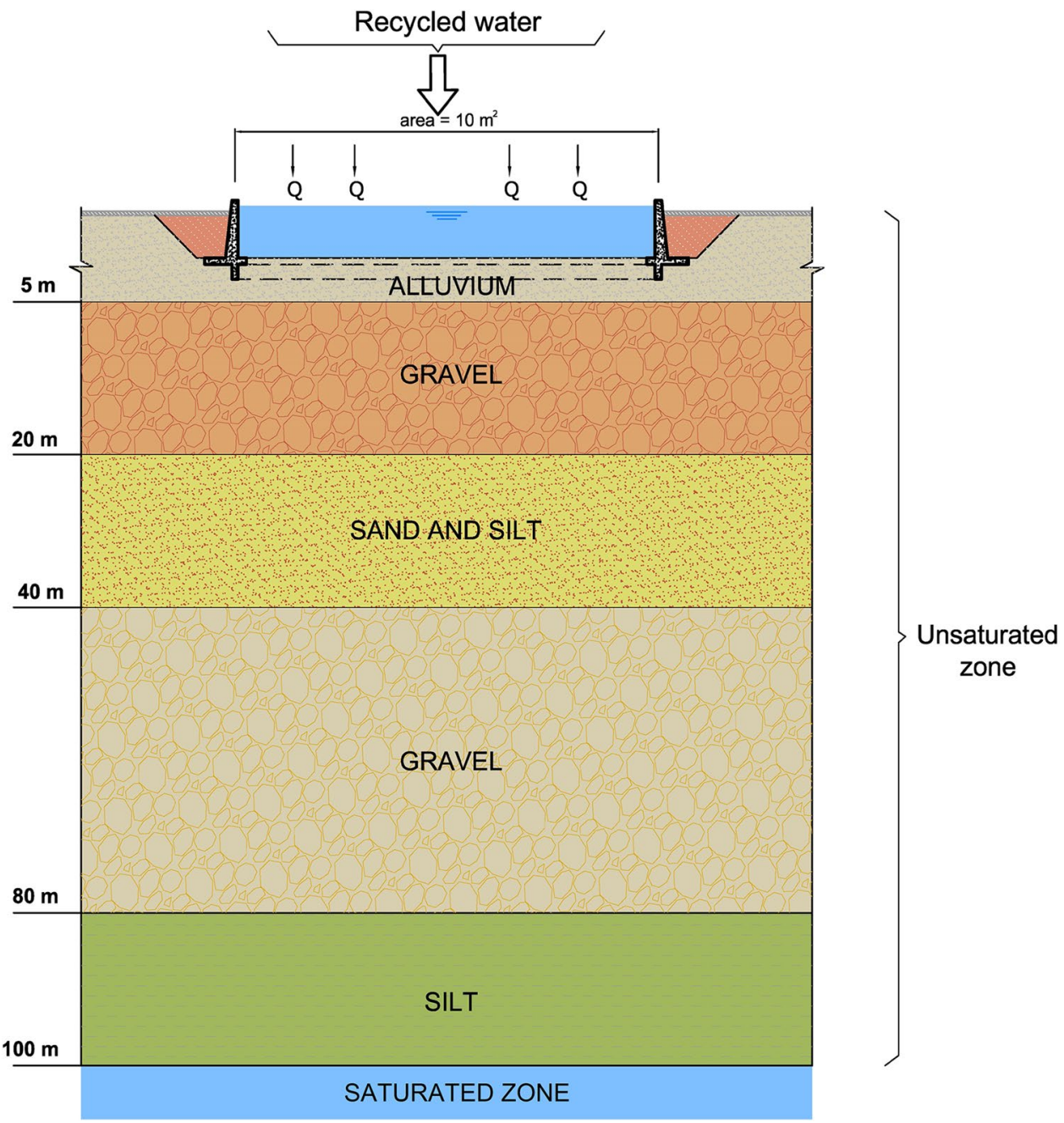

\begin{tabular}{|c|c|c|c|c|}
\hline Water quality parameter & $\begin{array}{l}\text { Source water } \\
(\mathrm{mg} / \mathrm{l})\end{array}$ & $\begin{array}{l}\text { Native ground- } \\
\text { water }(\mathrm{mg} / \mathrm{l})\end{array}$ & $\begin{array}{l}\text { NOM-014 } \\
(\mathrm{mg} / \mathrm{l})\end{array}$ & NOM-127 (mg/l) \\
\hline Fecal coliform organisms (n/100 ml) & 0 & & & 0 \\
\hline Chloride & & 22.20 & & 250 \\
\hline Hardness $\left(\mathrm{CaCO}_{3}\right)$ & & 200 & & 500 \\
\hline Fluorides & & 3 & & 1.50 \\
\hline Iron & & 0.04 & & 0.30 \\
\hline Phosphorus & 2.14 & & & \\
\hline Manganese & & 0.021 & & 0.15 \\
\hline Nitrates & 5.30 & 4.65 & & 10 \\
\hline Nitrites & 0.05 & & & 1 \\
\hline Sodium & & 58.89 & & 200 \\
\hline Total dissolved solids & & 440 & & 1000 \\
\hline Sediment solid & 0 & & & \\
\hline Total suspended solids & 50 & & & \\
\hline BOD & 23.10 & & 30 & \\
\hline DOC & 89.31 & & & \\
\hline TOC & & & 16 & \\
\hline Sulfates & & 72.17 & & 400 \\
\hline Methylene blue active substances & 0.10 & & & 0.50 \\
\hline
\end{tabular}




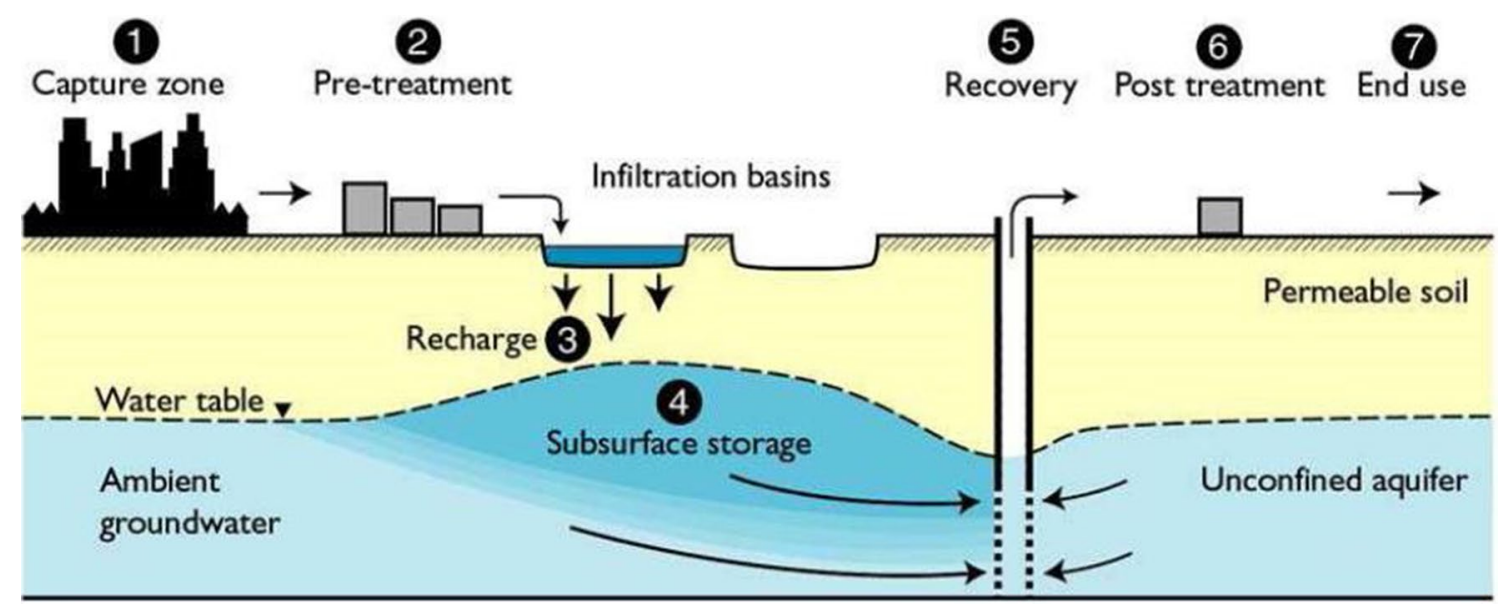

Fig. 5 Diagram of soil-aquifer treatment of treated wastewater (from NRMMC, EPHC, NHMRC 2009—Australian Guidelines for MAR)

floor of the basin when containing water by infiltrometer studies was $0.7 \mathrm{~m} /$ day and the maximum depth of ponded water was considered to be $1 \mathrm{~m}$ of water. This led to a conceptual design of the test pilot site with a square pond of $100 \mathrm{~m}^{2}$ of infiltration surface area, bounded by reinforced concrete walls. Water enters through an existing secondary channel that is derived from the main channel of the treated effluent of the SWWTP.

The excavation depth is $1 \mathrm{~m}$. It was proposed that the tank have a free border of $0.35 \mathrm{~m}$, which gives a wall of $1.35 \mathrm{~ms}$. In addition to the abovementioned, a screen of $0.35 \mathrm{~m}$ of depth was added with the objective of preserving the stability of the cementing shoes (Fig. 6). Provision was made for

\section{Pilot test design}

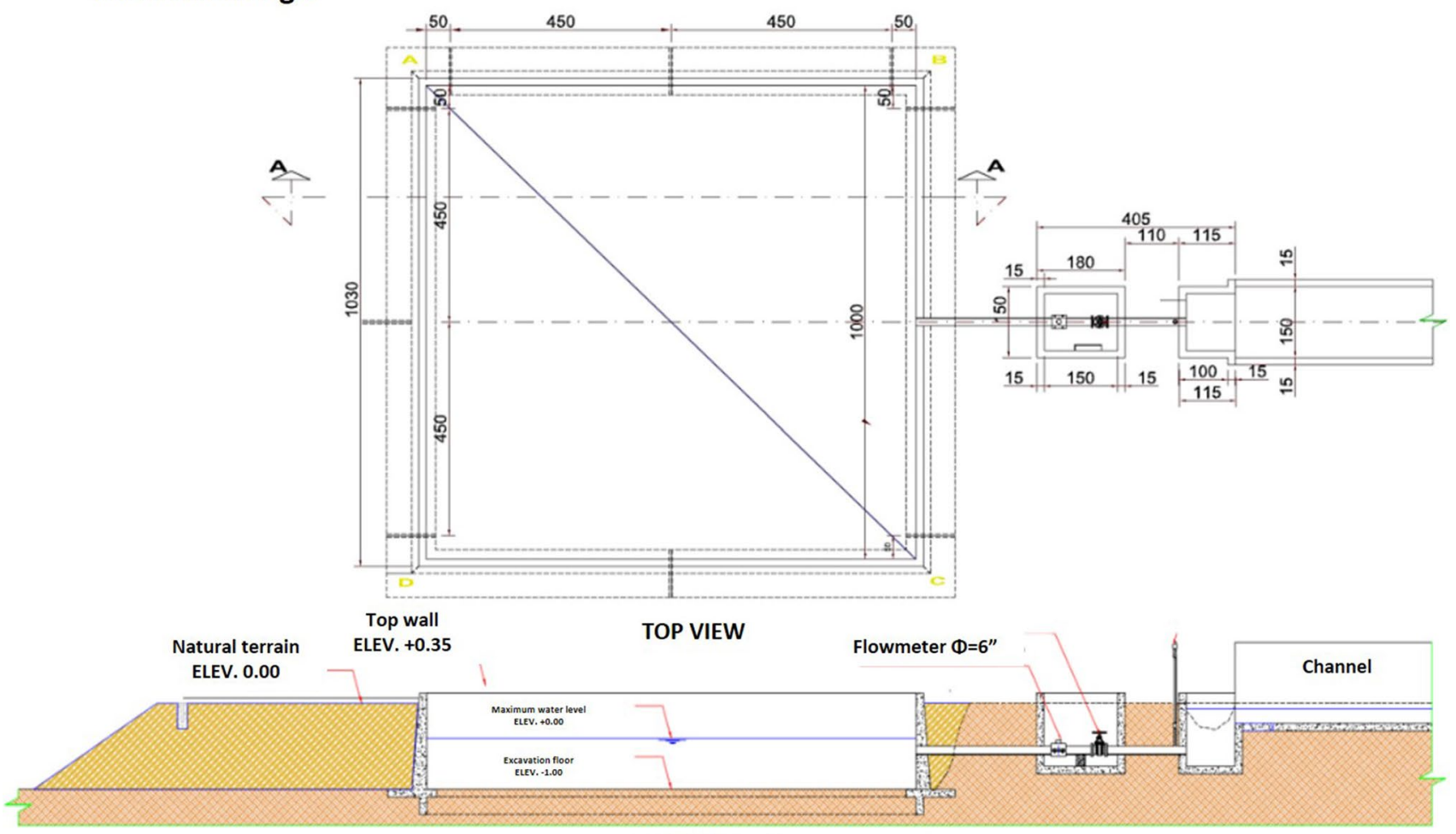

SECTION A - A

Fig. 6 Diagram of the design of the pilot test basin 
the ability to periodically scrape the surface of the basin as needed to remove an anticipated bioclogging layer.

\section{Plan for operation of the trial}

Infiltration operation consists on alternating wet-dry cycles in the lagoon to help achieve complete mineralization of the organic matter contained within the treated wastewater and soils (Hernández et al. 2017).

The number of wetting-drying cycles and their periodicity were calculated considering that the system works with continuous flow when wet and that the source water has been subjected to a secondary treatment. In total, two design variables were considered during the wet-dry cycles that depend mainly on the water flow rate and the permeability of soils. Stages of 5 days/10 days (wet/dry) were proposed, with an average residence time in the pond of $18 \mathrm{~h}(0.5 \mathrm{~m}$ divided by infiltration rate), see Fig. 7. The pond is to be operated to fill until $1 \mathrm{~m}$ depth is achieved and then drained, with rate of fill adjusted so that the basin drains 5 days after inflow commenced.

Maintenance of these facilities consists on the periodic removal of deposited fine material in the infiltration lagoon, approximately every 3 months. It is also necessary to avoid the growth of vegetation, which typically may impede infiltration rates. It is recommended that the delivery systems and valves are cleaned once a year with pressurized water.

\section{Operation and monitoring of the trial}

The pilot project will be operated for at least 6 months to collect and analyze data (Fig. 8). NOM-014 requires that all artificial recharge pilot projects include a monitoring program that periodically (before and during the operation) evaluates the following: (a) the quality of the recharge water; (b) the quality of mixed recharge water-native groundwater; and (c) the piezometric head measurements at the infiltration pond and groundwater, for a minimum period of 6 months.

Following the guidance in NOM-014, secondary treated wastewater recharge water will be sampled biweekly and the groundwater quality once a month. The water quality samples will be analyzed in accordance with the parameters outlined in the NOM-127-SSA1-1994 (1994), and in the parameters of Table 3 of the normative appendix "A" of the NOM-014, see Table 2.

Three nested monitoring wells were designed and located based mainly on groundwater flow directions and lithology. Well 1 is located at a distance of $1 \mathrm{~m}$ from the lagoon, and it has a total depth of $30 \mathrm{~ms}$, while well 2 is located at a distance of $5 \mathrm{~ms}$ from the infiltration pond at a depth of $60 \mathrm{~ms}$. The third well is located at a distance of $10 \mathrm{~ms}$ from the infiltration pond with a total depth of $102 \mathrm{~ms}$.

The instrumentation of each well allows measurement of the parameters of interest for this study, including: water levels, hydraulic conductivity, temperature, and $\mathrm{pH}$. Additionally, it is planned to install a suction-cup lysimeter or other form of water sampling in each monitoring location for subsequent analysis in the laboratory to fulfill the monitoring requirements of NOM-014.

\section{Vadose zone model of fate of water and solutes}

The study area was conceptualized with five horizontal layers of porous media with contrasting permeability. The vadose zone model was configured based on the geological model derived from the geophysical survey. The flow model considers the planned operation of the basin with (wet/dry cycles) as described above.

The numerical flow modeling employs Richards equation for single-phase flow (liquid phase), using a finite-difference scheme in a two-dimensional vertical slice through the center of the basin to below the water table. Likewise, the numerical modeling of solute transport in unsaturated media
Fig. 7 Conceptual operational schedule for one wet-dry cycle of the pilot basin trial

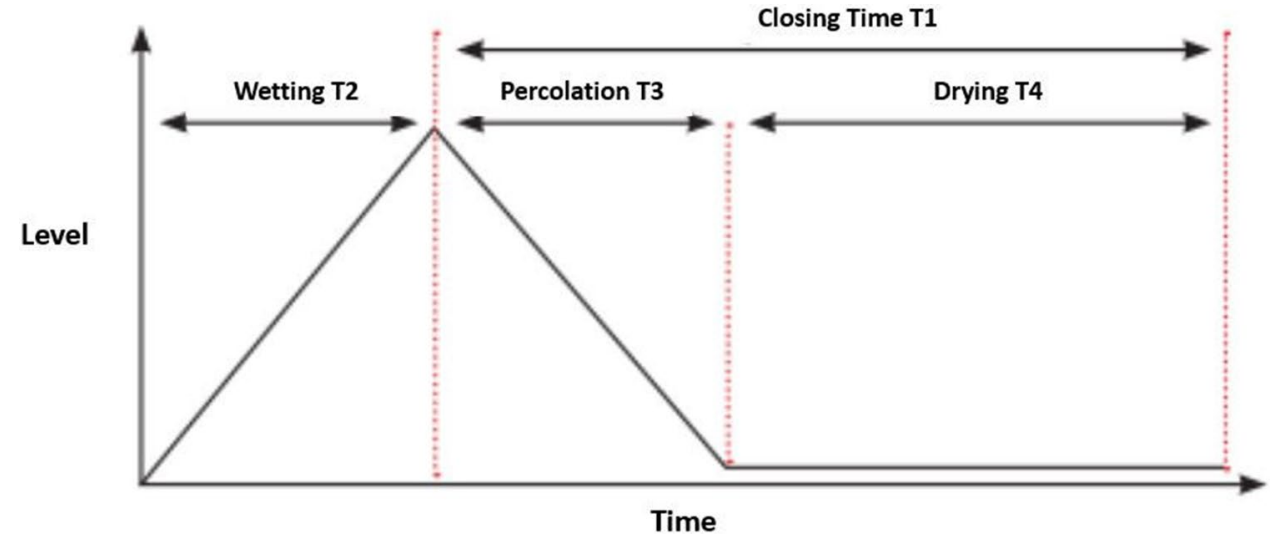




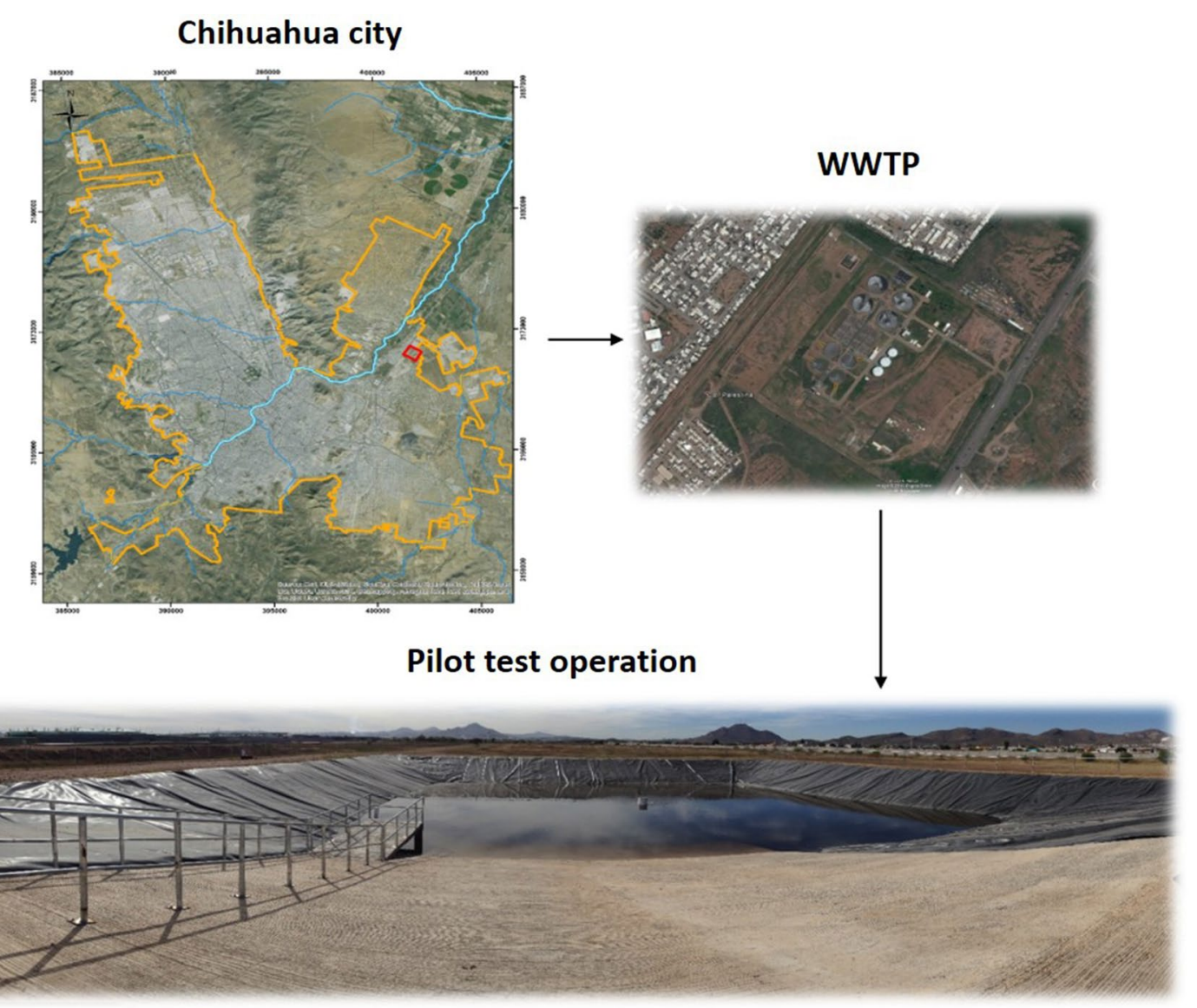

Fig. 8 Location of the working pilot test

consists of the solution of the advection-dispersion equation. Both models were developed using the public domain code VS2DTI-Variably Saturated Porous Media (2D) for Simulation of Water and Solute Transport, developed by the U. S. Geological Survey (Healy and Ronan 1996).

The simulation produces a time series of two-dimensional fields of simulated variables; moisture content, saturation, pressure potential, total potential and velocity fields and solute concentration. The solute transport solution has been run with two scenarios: conservative transport of solutes and reactive transport (with linear sorption with and without degradation).

The horizontal numerical discretization involves 30 columns of cells with $\Delta x=1 \mathrm{~m}$, extending $10 \mathrm{~m}$ each side of the basin. The vertical discretization uses 73 rows of cells with $\Delta z$ varying from 0.5 to $2 \mathrm{~m}$ depending on the proximity to the basin and to material layer boundaries. Hence, the model has 2190 active cells.

Two types of recharge periods are defined: a. A refill period with infiltration: corresponding to the period that includes the filling cycle of the pilot lagoon with a 5-day duration; and

b. A period without infiltration: corresponding to the period comprising the drying cycle of the pilot lagoon with a 10-day duration.

Flow simulations indicate that the porous media in the first $40 \mathrm{~m}$ from the soil surface determine the rate of infiltration. In these strata, the moisture content, and hence degree of saturation, are higher in media of lower permeability that drain more slowly. In contrast, the low saturation reached by the gravel layer indicates that it is able to drain water from above more quickly. Thus, the difference in saturation indices between the materials described reveals that the first three strata determine the infiltration rate in the vadose zone with relative independence to the lower two, even though one of these has the lowest hydraulic conductivity in the profile. The wet 'bulb' present in the unsaturated zone, initiates contact with the static water table level after approximately 270 days (Fig. 9). 


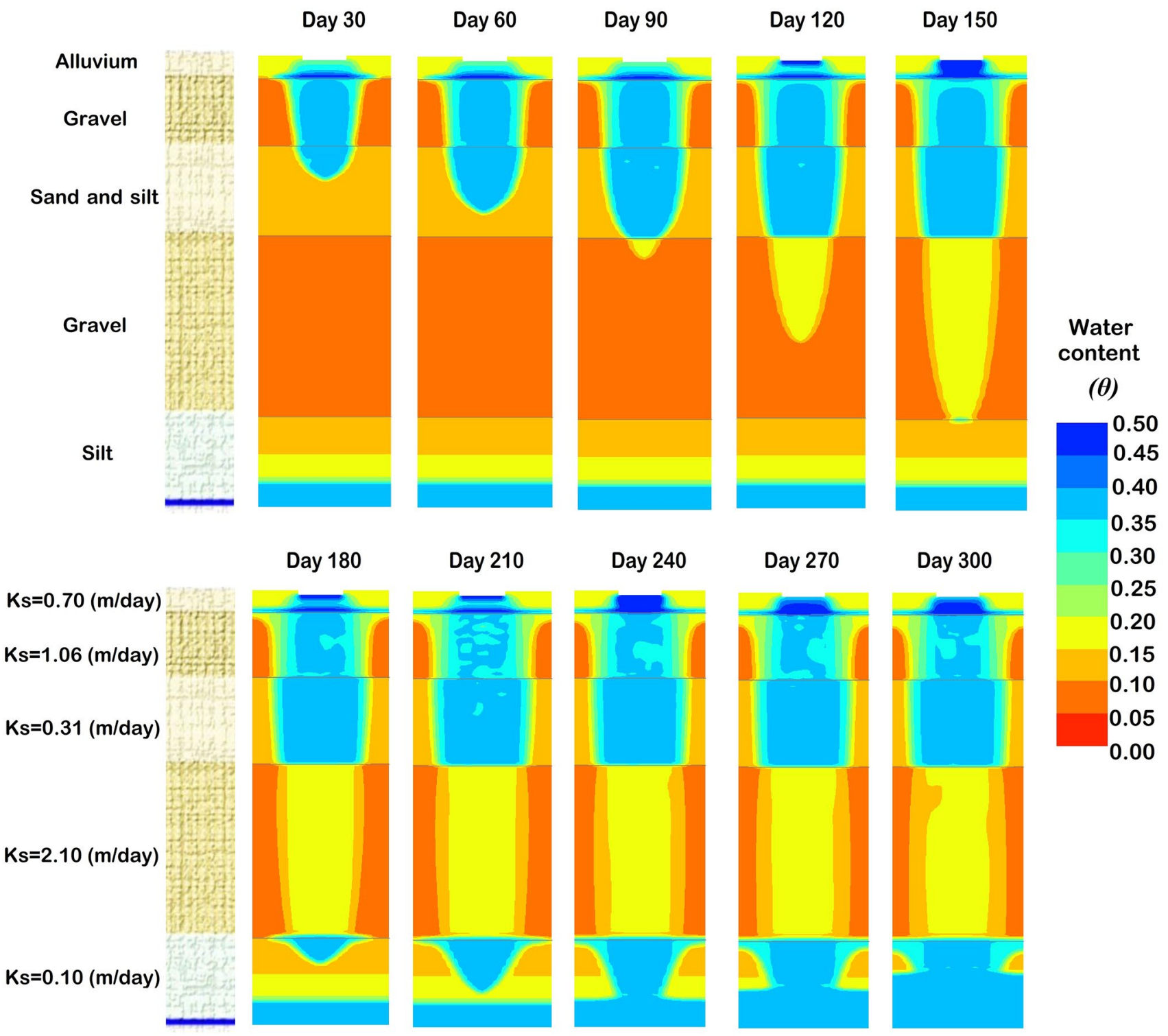

Fig. 9 Vadose zone model results for saturation (dimensionless)

On the other hand, in the transport simulations (Fig. 10), a constant concentration of conservative solute in the water infiltrated over 6 months takes approximately one and a half years to reach the aquifer without absorption or retardation processes. This suggests that 6 months of recharge may be too short an operating period to gain reliable information about contaminant migration due to the reduced rate of downward movement that occurs when the basin is not being used. The lack of a hydraulic driver could be wrongly interpreted as sorption or degradation in the unsaturated zone. This illustrates the value of a good characterization of the unsaturated zone and unsaturated zone modeling in informing experimental design for pilot projects. Note that further consideration should be given to particulate transport, particularly for viruses and their analogues, as in some circumstances, such as where preferential flow paths occur, these may be more mobile than even conservative solutes, and be consequential for health impacts.

\section{Conclusions}

The application of the Mexican Guidelines for aquifer recharge with treated wastewater (NOM-014) at Chihuahua City demonstrates a logical approach to water quality protection of an aquifer under threat of depletion. Although it is still at an early stage of investigations, the value of a staged approach to risk assessment, also shared with the Australian Guidelines for MAR (NRMMC, EPHC and NHMRC 


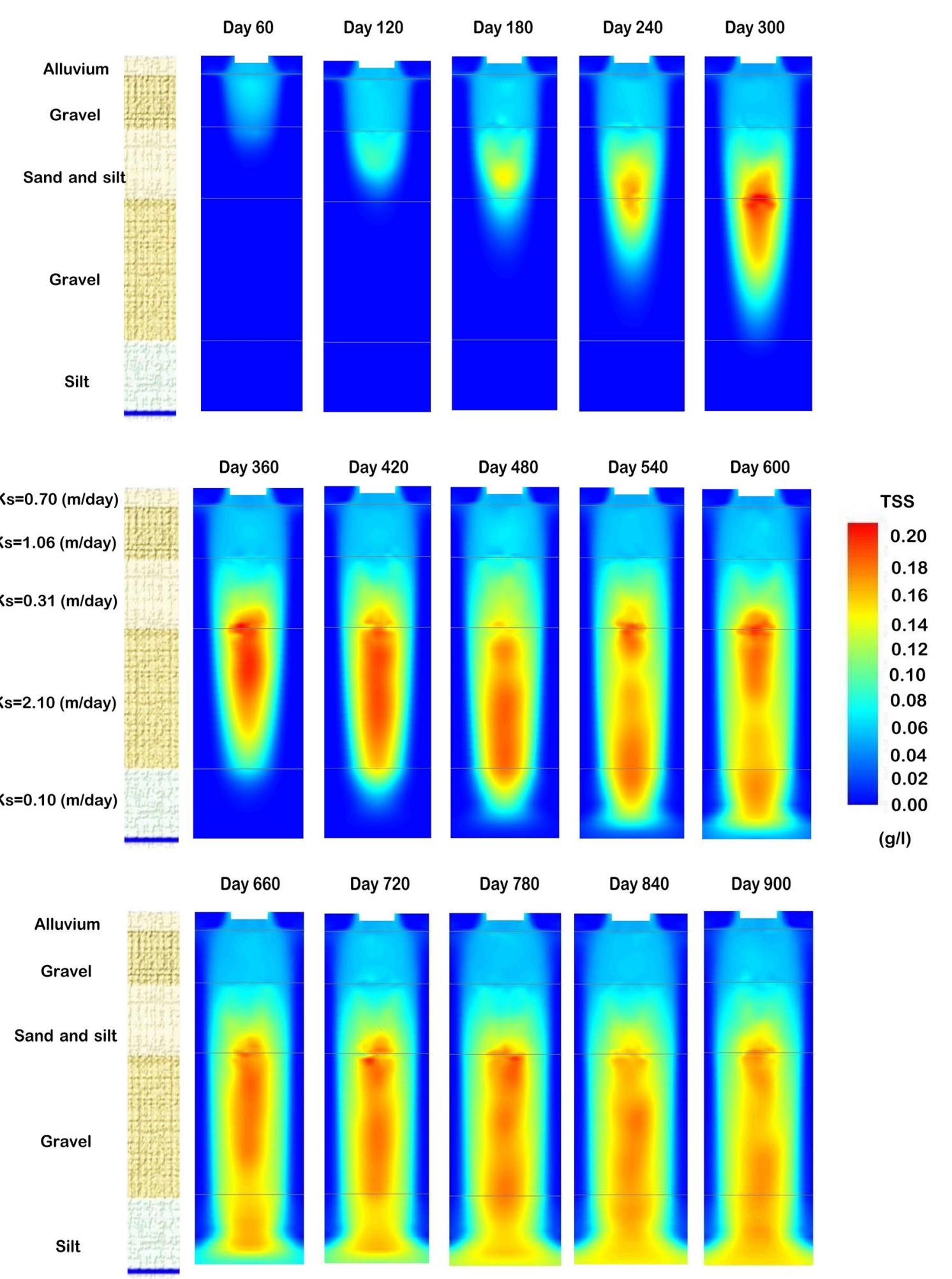

Fig. 10 Vadose zone model results for conservative transport simulation of total suspended solids (g/l) 
2009), quickly becomes apparent. The site selection process is logical and constrained by easily available information. Water quality comparisons between native groundwater, the source water for recharge, in this case secondary treated sewage effluent, and the various applicable standards in Mexico allowed an understanding of which parameters need to be attenuated in the unsaturated zone, and by how much to meet the requirements.

Site characterization is very important and in this case was performed with a single production well with a geological log supported by a vertical electrical sounding geophysical survey that enabled a layered geological conceptual model to be developed. This model allowed the intended pilot operation to be simulated and the fate of water and solutes to be predicted. The preliminary results suggest that the duration of the trial will likely need to be extended to validate the treatment capacity of the vadose zone. Once operational data become available the model can be refined and rerun if necessary and assist in planning of a large scale operation.

Design of these systems pose challenges and already the initial design which had vertical concrete perimeter walls has been modified to allow for easier scraping of sediments from the surface of the infiltration basin, as will be required periodically. Soil solution sampling from significant depths also poses challenges and, on this site, such measurements are likely to be a key to estimating long term removal of consequential solutes in the vadose zone.

Although it is too early to conclude that this operation will be a success, the pathway to success has been laid and should the vadose treatment be inadequate, the options are to change operating arrangements such as the length of wet and dry cycles, or enhancing the treatment of the effluent prior to recharge. This would enable a clearer picture of costs and benefits of a full-scale project before making such investment.

The pilot project presented here offers an opportunity to improve the integrated management of the resource in the basin, and suggest opportunities elsewhere. Incrementing groundwater storage with recycled water is a strategy of great value, principally in arid and semi-arid areas of the country to solve the sustainable handling of the resource in situations of shortage and climatic change.

Managed aquifer recharge in Mexico is developing, thanks in no small part to the existence of the Mexican guidelines (González et al. 2015). These are enhancing the information and knowledge to improve understanding, design, and operation and monitoring of these types of projects. However, one limitation on progress with managed aquifer recharge has been continuous turnover in senior personnel in water boards who are in charge of the operation and supply of water.

It is needed to inform them of these published water regulations that are now 10-years-old and should by now be bedded down and regarded as normal practice. Perhaps more efficient ways of informing senior managers are required to capture the benefits that Mexico is now poised to obtain.

Acknowledgements The authors want to acknowledge Peter Dillon, Timothy Parker and Alfonso Rivera for the commentaries for this paper.

Open Access This article is distributed under the terms of the Creative Commons Attribution 4.0 International License (http://creativeco mmons.org/licenses/by/4.0/), which permits unrestricted use, distribution, and reproduction in any medium, provided you give appropriate credit to the original author(s) and the source, provide a link to the Creative Commons license, and indicate if changes were made.

\section{References}

Arévalo Ruiz JF, Pérez Venzor J, González Castañeda C (2006) Exploración geohidrológica en la zona de Ojo Laguna-Sierra El Nido. Chihuahua

CONAGUA (2007) NOM-014-Requisitos para la recarga artificial de acuíferos con agua residual tratada

Dillon P, Toze S, Page D, Vanderzalm J, Bekele E, Sidhu J, RinckPfeiffer S (2010) Managed aquifer recharge: rediscovering nature as a leading edge technology. Water Sci Technol 62:2338-2345. https://doi.org/10.2166/wst.2010.444

González Villarreal F, Cruickshank Villanueva C, Palma Nava A, Mendoza Mata A (2015) Recarga Artificial de Acuíferos en México. Revista $\mathrm{H}_{2} \mathrm{O}$, del Sistema de Aguas de la Ciudad de México. Año 2. Enero-Marzo

Healy RW, Ronan AD (1996) Documentation of computer program VS2DH for simulation of energy transport in variably saturated porous media-modification of the U.S. Geological Survey's computer program VS2DT: U.S. Geological Survey WaterResources Investigations Report 96-4230, p 36

Hernández Aguilar H, Campuzano Chávez R, Valenzuela Vásquez L, Ramírez Hernández J (2017) Aquifer recharge with treated municipal wastewater: long-term experience at San Luis Río Colorado, Sonora. Sustain Water Resour Manag. https://doi.org/10.1007/ s40899-017-0196-2

Hernandez López A (2017) Métodos geofísicos para la determinación de características de acuíferos para su recarga artificial mediante lagunas de infiltración. Tesis de Licenciatura. Facultad de Ingeniería, UNAM, Ciudad de México

NOM-127-SSA1-1994 (1994) Salud ambiental, agua para uso y consumo humano-Límites permisibles de calidad y tratamientos a que debe someterse el agua para su potabilización

NRMMC, EPHC, NHMRC (2009) Australian guidelines for water recycling, managing health and environmental risks, Volume 2C-managed aquifer recharge. Natural Resource Management. http://webarchive.nla.gov.au/gov/20130904195601/http:// www.environment.gov.au/water/publications/quality/water-recyc ling-guidelines-mar-24.html. Accessed 2 Feb 2018 